\title{
EDITORIAL
}

\section{Genome Medicine: past, present and future}

\author{
Charles Auffray ${ }^{1 *}$, Timothy Caulfield ${ }^{2 *}$, Muin J Khoury ${ }^{3 *}$, James R Lupski ${ }^{4,5 *}$, Matthias Schwab ${ }^{6,7 *}$ and Timothy Veenstra ${ }^{8 *}$
}

The field of genomic medicine continues to expand, driven by the efforts of numerous researchers around the world. To celebrate Genome Medicine's 2nd anniversary, we asked our Section Editors what they felt were the most exciting breakthroughs in research in the past 2 years and what the future of genomic medicine might hold.

\section{Transformational effect of systems medicine}

Since we discussed systems medicine as the future of medical genomics and healthcare in the inaugural issue of Genome Medicine [1], the field has witnessed transformational changes that have brought the prospect and promises of personalized medicine closer to reality. The exponential increase in DNA sequencing capabilities, together with the rapidly declining associated costs, has made whole-genome sequencing accessible to small laboratories, and will soon transform it into a low cost analytical assay. These advances have enabled the emergence of medical systems genetics studies, an approach in which the genetic determinants of diseases are investigated through sequencing of the complete genome of family relatives. For example, sequencing and analysis of the genomes of two siblings and their parents made possible the direct measurement of the inter-generational mutation rate and identified genes potentially associated with two Mendelian disorders [2]; the gene causing one of these disorders was precisely identified through further exome sequencing in additional diseased patients [3]. Another telling example of both the power and current limitations of the next-generation sequencing approaches is their application to the characterization of the genome, epigenome and transcriptome of monozygotic twins discordant for multiple sclerosis, which failed to uncover significant differences associated with the disease [4]. With several thousand genomes now being completed, and tens of thousands anticipated in the coming year, the limitation is already to a large extent, and will increasingly be, on the side of data analysis, as the collection, storage

*All authors contributed equally

Full list of author information is available at the end of the article and analysis of the large datasets generated requires the combined expertise of a wide variety of scientists, engineers and physicians [5]. Fortunately, the software, databases and computing power required for these community efforts are now becoming available through computer grids and cloud computing infrastructures, offering an affordable alternative for genome and translational bioinformatics [6,7]. Combined together, genome sequencing and cloud computing will contribute to bridging the gap between systems biology and medicine by opening the way to the precise and low cost assays that are necessary for systems medicine to become a practical alternative to traditional reactive medicine [8].

Charles Auffray, Section Editor, Systems medicine and informatics

\section{The public perception challenge}

Public perception research has long been a big part of the ethical, legal and social issues (ELSI) research agenda. Over the past decades a wide range of methods have been deployed to tease out how the public (whatever that might be) feels about everything from gene patents to genetic privacy to the utility of direct-to-consumer testing services. However, understanding public perceptions has never been more important than it is now. Genomic research requires even more research participants, through such initiatives as large population biobanking studies. And the clinical value of many proposed genomic interventions depends on a public response to genebased risk information (such as the promotion of healthy lifestyle changes). Understanding how the public views and is likely to respond to genetic information will have an impact on both the nature of research that can be done and whether we will derive social benefit from that research. Recent public perception research has demonstrated that the challenges in both of these areas could be profound. For example, a study that included 16 focus groups and a survey of over 4,000 individuals concluded that the public wants ongoing control over their genetic samples that have been donated for research [9]. Subsequent studies have come to similar results [10]. People want 'control.' They want to consent. But can we give meaning to this public desire and still carry out big genomic studies? The research on how people respond to 
genomic information is also illuminating and somewhat deflating, at least from a public health perspective. The emerging data, wonderfully summarized in a recent Cochrane Collaboration review [11], highlights that the public response to genetic risk information seems likely to be rather muted [12]. Given this reality, at least one aspect of the long promised benefits of genomicsinformed personalized medicine - that is, the promotion of individualized preventive health strategies - may not pan out as expected. What is probably needed is both a more realistic appraisal of how genetic information will assist approaches to public health and more research into the ways in which genetic information can supplement, if at all, existing disease risk information.

Timothy Caulfield, Section Editor, Social, ethical and legal issues in genomic medicine

\section{The translational gap in genomic medicine}

Rapid advances in genomics and related technologies are promising a new era of personalized healthcare and disease prevention, including new drugs, diagnostic and screening tests based on individual genetic makeup and disease biomarkers. Scientists predict that the age of personalized health care has arrived. Nevertheless, the gap is still wide between new discoveries and their clinical validity and utility in practice [13]. The expansion of direct-to-consumer marketing of personal genome profiles for risk assessment and disease prevention illustrates the premature deployment of this technology without the appropriate evidence base to support their use in practice [14]. If the promise of genomics is to be fulfilled, we must use scientific methods to document how such technologies can improve health and prevent disease in practice. Dealing with the genomics evidence gap will require two key and interrelated science and policy areas, which are crucial to accelerating the appropriate translation of genomics into clinical practice. The first is to develop a multidisciplinary translation research agenda, including more clinical and population-based research, in the life cycle of research from the bench to improved population health outcomes $[15,16]$, and the second is to develop a stakeholder collaboration to effect evidence-based translation. Translation research is necessary, but not sufficient, to move specific genomic applications from research into practice. Actual translation is even more complicated. Different forces can accelerate or impede the translation process, such as private investments in research and development, policy and legal frameworks, oversight and regulation, product marketing, coverage and reimbursements, consumer advocacy, provider awareness, access, and health services development and implementation $[17,18]$.

Muin Khoury, Section Editor, Genomic epidemiology and public health genomics

\section{Genome Medicine and personal genomics}

In order for the discipline of genomic medicine to fulfill its maximum potential and utility in the clinic, it is necessary to be able to characterize all forms of genetic variation in an individual patient's genome. This includes single or simple nucleotide variation (SNV) and copy number variation $(\mathrm{CNV})$. Personal genome sequencing is becoming a reality. The complete nucleotide sequence of James Dewey Watson, 55 years after his discovery of DNA and two decades after he led the human genome project, provided tremendous insights into personal genomes. It was the first human genome sequenced by next generation sequencing [19] and revealed extensive variation: greater than 3 million SNV differences in comparison with the reference haploid human genome sequence and a high frequency of small sized CNVs (less than $1 \mathrm{~kb}$ ) that were beyond the detection limits of array comparative genomic hybridization. Another major finding was the amount of $A l u$ repetitive element polymorphisms - indels (insertions or deletions) representing dimorphisms of $A l u$ at a particular locus. Thus, for each personal genome the amount of structural variation related to the position of repetitive elements could be immense. The remarkable extent of genome structural variation in populations was further revealed by Conrad et al. [20].

The next important step in personal genomics was to use whole-genome sequence to associate specific variation with clinical disease phenotypes, and thus identify medically actionable variation from the myriad of benign polymorphic variations; that is, detect signal from noise. Whole-genome sequencing (WGS) was used to identify the cause of Charcot-Marie-Tooth neuropathy. Surprisingly, this work also provided insights into genetic variation underlying common complex traits such as carpal tunnel syndrome [21]. Whole exome sequencing (WES) has also now been used to find the medically actionable alleles in defined clinical Mendelian phenotypes for which the causative genes were unknown (for example, [3,22-24]), and to make a definitive diagnosis for a patient with a complex trait [25]. Further exome sequencing work recently documented that new mutations may contribute in a significant way to common traits such as mental retardation and intellectual disability [26]. This latter study emphasizes the importance of personal genomics for assessing not only inherited variation but also de novo events.

However, we must not lose sight of the challenges! Exome sequencing provides essentially no information about structural variation and CNV. Whole-genome sequencing can provide structural variation information, but it is not obvious to what extent short read sequences can capture CNV, such as those of only a few hundred base pairs that may delete or duplicate single exons [27] or delineate complex rearrangements, given the 
information filtering step required in matching short reads to a haploid human reference genome. Whether or not WES or WGS will discern repeat expansion, a highly significant form of pathology-associated genetic variation, also remains to be demonstrated. Nevertheless, from the insights already provided, it is clear that the information that can be gleaned from personal genome sequencing will probably be so compelling that clinicians will be motivated to rapidly adapt it into clinical practice.

James R Lupski, Section Editor,

Molecular genetics, genomics and epigenetics of disease

\section{The paradigm-shift of personalized medicine}

The modern concept of personalized medicine is stimulated by the idea that genomic medicine may help to prevent and/or treat diseases by the use of the individual genetic information of the host, tumor and/or other biological organisms (such as bacteria). Pharmacogenomics, a distinct discipline within the field of personalized medicine, includes the study of the influence of genetic variation on drug response, but also comprises the genome-wide and multi-factorial extension. Thus, in the modern conception of personalized medicine, the tools that are provided to the physician are hopefully more precise, considering not just the obvious, such as a malign tumor by computer tomography, but the individual genetic make-up of the patient. There are several examples in which a profile of a patient's genetic variation is used to guide the selection of drugs or treatment processes, leading to a more successful outcome from the medical treatment [28]. The question is no longer what if this could happen in clinical practice, but when. Consideration of new 'omics-based biomarkers for patient stratification should by no means exclude the use of traditional biomarkers, such as a patient's age, body composition, physical examination findings, blood pressure, and so on, for diagnosis of disease and choice of prevention or treatment. However, personalized treatment needs to combine clinical assessment and disease diagnostic tests with treatment-related (genetic) tests. In addition to biomarkers predicting the efficacy and, if possible, effectiveness of a treatment, sufficient attention must also be given to the use of biomarkers for predicting drug safety. Considerable research activities in biomarker discovery and validation are ongoing, but little is being done to bring this information into clinical practice [29]. The cost of sequencing the human genome falls and whole-genome sequencing is already occurring, but data interpretation requires expertise not only related to the genetics of disease, but also related to pharmacological principles. Continuing Medical Education courses on personalized medicine, particularly with focus on genomic issues, need to be made available to bring physicians to the latest technological developments. To this end there is still a substantial need to demonstrate the potential added value that personalized genomicbased approaches bring, in particular the added value of patient stratification in view of improved effectiveness and/or reduction of adverse side effects.

Matthias Schwab, Section Editor, Personalized medicine and therapeutics

\section{From sensitive technologies to clinical action}

Undoubtedly the greatest advances in translational medicine over the past decade have been in the area of genetics. The advent of next-generation sequencing technologies have made genome-wide association studies, the identification of large numbers of single nucleotide polymorphisms and copy number variants that influence disease possible. In the post-genomic era, the hope is that advances in proteomic measurements can mimic those made in genetics. Although progress has not been as dramatic, technologies for protein measurements are making important strides in translational medicine. If proteomic technologies are to have an impact on translational medicine, however, they must be adaptable to analyzing clinic samples. This requirement means analyzing small volumes of biofluids and thin tissue sections, both fresh frozen and formalin-fixed. One of the most important developments to achieving this goal is the increasing sensitivity provided by mass spectrometers. In the past highly sensitive mass spectrometers were limited to specialized mass spectrometry (MS) laboratories. Nowadays, instruments that routinely measure sub-femtomole levels of proteins in complex biological matrices are being widely used in traditionally non-MS laboratories. Thousands of proteins can now be identified from as little as $100 \mu \mathrm{l}$ of blood [30]. Laser capture microdissection of approximately 5,000 cells from thin tissue sections can now provide upwards of 2,500 confident protein identifications [31]. With the development of methods to extract proteins from formalin-fixed tissue sections, MS can now analyze a seemingly inexhaustible source of tissues from countless tumor types [32]. The sensitivity provided by modern mass spectrometers leads to greater proteomic coverage for identifying disease-specific biomarkers and enhancing the quantitative measurement of specific proteins in clinical samples. Unfortunately, increased sensitivity compounds an existing problem specifically in the use of MS for the discovery of disease-specific biomarkers: turning data into information. The next big development in post-genomic medicine will be devising methods or bioinformatic tools to recognize potentially valuable protein biomarkers in the complex datasets generated using MS.

Timothy D Veenstra, Section Editor, Post-genomic advances in medicine 


\section{Abbreviations}

CNV, copy number variation; $M S$, mass spectrometry; SNV, simple nucleotide variation; WES, whole exome sequencing; WGS, whole-genome sequencing.

\section{Author details}

'Functional Genomics and Systems Biology for Health, CNRS Institute of Biological Sciences, 94801, Villejuif, France. ${ }^{2}$ Faculty of Law and School of Public Health, University of Alberta, 3-12 University Terrace, 8303-112 St. Edmonton, AB T6G 2T4, Canada. ${ }^{3}$ Office of Public Health Genomics, Centers for Disease Control and Prevention, 1600 Clifton Rd, NE, MS E61, Atlanta, GA 30333, USA. ${ }^{4}$ Departments of Molecular and Human Genetics and Pediatrics, Baylor College of Medicine, Houston, TX 77030, USA. ${ }^{5}$ Texas Children's Hospital, Houston, TX 77030, USA. 'Dr Margarete Fischer-Bosch Institute of Clinical Pharmacology, Auerbach Str. 112, 70367 Stuttgart, Germany. ${ }^{7}$ Department of Clinical Pharmacology, Institute of Experimental and Clinical Pharmacology and Toxicology, University Hospital, 72076 Tuebingen, Germany. ${ }^{8}$ Laboratory of Proteomics and Analytical Technologies, National Cancer Institute at Frederick, Frederick, MD 21702-1201, USA.

Published: 31 January 2011

\section{References}

1. Auffray $C$, Chen Z, Hood L: Systems medicine: the future of medical genomics and healthcare. Genome Med 2009, 1:2.

2. Roach JC, Glusman G, Smit AF, Huff CD, Hubley R, Shannon PT, Rowen L, Pant KP, Goodman N, Bamshad M, Shendure J, Drmanac R, Jorde LB, Hood L, Galas $D$ : Analysis of genetic inheritance in a family quartet by whole-genome sequencing. Science 2010, 328:636-639.

3. Ng SB, Buckingham KJ, Lee C, Bigham AW, Tabor HK, Dent KM, Huff CD, Shannon PT, Jabs EW, Nickerson DA, Shendure J, Bamshad MJ: Exome sequencing identifies the cause of a Mendelian disorder. Nat Genet 2010, 42:30-36.

4. Baranzini SE, Mudge J, van Velkinburgh JC, Khankhanian P, Khrebtukova I, Miller NA, Zhang L, Farmer AD, Bell CJ, Kim RW, May GD, Woodward JE, Caillier SJ, McElroy JP, Gomez R, Pando MJ, Clendenen LE, Ganusova EE, Schilkey FD, Ramaraj T, Khan OA, Huntley JJ, Luo S, Kwok PY, Wu TD, Schroth GP, Oksenberg JR, Hauser SL, Kingsmore SF: Genome, epigenome and RNA sequences of monozygotic twins discordant for multiple sclerosis. Nature 2010, 464:1351-1356.

5. Mardis $\mathrm{E}:$ The $\$ 1,000$ genome, the $\$ 100,000$ analysis? Genome Med 2010 , 2:84

6. Stein LD: The case for cloud computing in genome informatics. Genome Biol 2010, 11:207.

7. Dudley JT, Pouliot Y, Chen R, Morgan AA, Butte AJ: Translational bioinformatics in the cloud: an affordable alternative. Genome Med 2010, 2:51

8. Clermont G, Auffray C, Moreau Y, Rocke DM, Dalevi D, Dubhashi D, Marshall DR, Raasch P, Dehne F, Provero P, Tegner J, Aronow BJ, Langston MA, Benson $M:$ Bridging the gap between systems biology and medicine. Genome Med 2009, 1:88.

9. Murphy J, Scott J, Kaufman D, Geller G, LeRoy L, Hudson K: Public perspectives on informed consent for biobanking. Am J Public Health 2009, 99:2128-2134

10. Ludman EJ, Fullerton SM, Spangler L, Trinidad SB, Fujii MM, Jarvik GP, Larson EB, Burke W: Glad you asked: participants' opinions of re-consent for dbGap data submission. J Empir Res Hum Res Ethics 2010, 5:9-16.

11. Marteau TM, French DP, Griffin SJ, Prevost AT, Sutton S, Watkinson C, Attwood S, Hollands GJ: Effects of communicating DNA-based disease risk estimates on risk-reducing behaviours. Cochrane Database Syst Rev 2010, 10:CD007275

12. McBride CM, Koehly LM, Sanderson SC, Kaphingst KA: The behavioral response to personalized genetic information: will genetic risk profiles motivate individuals and families to choose more healthful behaviors? Annu Rev Public Health 2010, 31:89-103.

13. Khoury MJ: Dealing with the evidence dilemma in genomic medicine. Clin Pharmacol Ther 2010, 87:635-638.

14. Khoury MJ, MCBride C, Schully SD: The scientific foundation for personal genomics: recommendations from an $\mathrm{NIH}-\mathrm{CDC}$ multidisciplinary workshop. Genet Med 2009, 11:559-567.

15. Khoury MJ, Gwinn M, loannidis JP: The emergence of translational epidemiology: from scientific discoveries to population health impact. $A m$ J Epidemiol 2010, 172:517-524.
16. Schully SS, Benedicto C, Wang SS, Gillanders E, Khoury MJ: Translational research in cancer genomics: the road less travelled. Public Health Genomics 2011, 14:1-8

17. Khoury MJ, Feero WG, Reyes M, Citrin T, Freedman A, Leonard D, Burke W, Coates R, Croyle RT, Edwards K, Kardia S, McBride C, Manolio T, Randhawa G, Rasooly R, St Pierre J, Terry S; GAPPNet Planning Group: The genomic applications in practice and prevention network. Genet Med 11:488-494.

18. CDC: Genomic Applications in Practice and Prevention Network (GAPPNet ${ }^{\mathrm{T}}$ ) [http://www.cdc.gov/genomics/translation/GAPPNet/index.htm/]

19. Wheeler DA, Srinivasan M, Egholm M, Shen Y, Chen L, McGuire A, He W, Chen YJ, Makhijani V, Roth GT, Gomes X, Tartaro K, Niazi F, Turcotte CL, Irzyk GP, Lupski JR, Chinault C, Song XZ, Liu Y, Yuan Y, Nazareth L, Qin X, Muzny DM, Margulies M, Weinstock GM, Gibbs RA, Rothberg JM: The complete genome of an individual by massively parallel DNA sequencing. Nature 2008, 452:872-876.

20. Conrad DF, Pinto D, Redon R, Feuk L, Gokcumen O, Zhang Y, Aerts J, Andrews TD, Barnes C, Campbell P, Fitzgerald T, Hu M, lhm CH, Kristiansson K, Macarthur DG, Macdonald JR, Onyiah I, Pang AW, Robson S, Stirrups K, Valsesia A, Walter K, Wei J, Tyler-Smith C, Carter NP, Lee C, Scherer SW, Hurles ME: Origins and functional impact of copy number variation in the human genome. Nature 2010, 464:704-712.

21. Lupski JR, Reid JG, Gonzaga-Jauregui C, Rio Deiros D, Chen DC, Nazareth L, Bainbridge M, Dinh H, Jing C, Wheeler DA, McGuire AL, Zhang F, Stankiewicz P, Halperin JJ, Yang C, Gehman C, Guo D, Irikat RK, Tom W, Fantin NJ, Muzny DM, Gibbs RA: Whole-genome sequencing in a patient with CharcotMarie-Tooth neuropathy. NEng/ J Med 2010, 362:1181-1191.

22. Gilissen C, Arts HH, Hoischen A, Spruilit L, Mans DA, Arts P, van Lier B, Steehouwer M, van Reeuwijk J, Kant SG, Roepman R, Knoers NV, Veltman JA, Brunner HG: Exome sequencing identifies WDR35 variants involved in Sensenbrenner syndrome. Am J Hum Genet 2010, 87:418-423.

23. Hoischen A, van Bon BW, Gilissen C, Arts P, van Lier B, Steehouwer M, P de Vries, R de Reuver, Wieskamp N, Mortier G, Devriendt K, Amorim MZ, Revencu N, Kidd A, Barbosa M, Turner A, Smith J, Oley C, Henderson A, Hayes IM, Thompson EM, Brunner HG, de Vries BB, Veltman JA: De novo mutations of SETBP1 cause Schinzel-Giedion syndrome. Nat Genet 2010, 42:483-485.

24. Ng SB, Bigham AW, Buckingham KJ, Hannibal MC, MJ McMillin, Gildersleeve HI, Beck AE, Tabor HK, Cooper GM, Mefford HC, Lee C, Turner EH, Smith JD, Rieder MJ, Yoshiura K, Matsumoto N, Ohta T, Niikawa N, Nickerson DA, Bamshad MJ, Shendure J: Exome sequencing identifies MLL2 mutations as a cause of Kabuki syndrome. Nat Genet 2010, 42:790-793.

25. Worthey EA, Mayer AN, Syverson GD, Helbing D, Bonacci BB, Decker B, Serpe JM, Dasu T, Tschannen MR, Veith RL, Basehore MJ, Broeckel U, Tomita-Mitchell A, Arca MJ, Casper JT, Margolis DA, Bick DP, Hessner MJ, Routes JM, Verbsky JW, Jacob HJ, Dimmock DP: Making a definitive diagnosis: successful clinical application of whole exome sequencing in a child with intractable inflammatory bowel disease. Genet Med 2011, doi:10.1097/ GIM.0b013e3182088158.

26. Vissers LE, de Ligt J, Gilissen C, Janssen I, Steehouwer M, de Vries P, van Lier B, Arts P, Wieskamp N, del Rosario M, van Bon BW, Hoischen A, de Vries BB, Brunner $\mathrm{HG}$, Veltman JA: A de novo paradigm for mental retardation. Nat Genet 2010, 42:1109-1112.

27. Boone PM, Bacino CA, Shaw CA, Eng PA, Hixson PM, Pursley AN, Kang SH, Yang Y, Wiszniewska J, Nowakowska BA, del Gaudio D, Xia Z, Simpson-Patel G, Immken LL, Gibson JB, Tsai AC, Bowers JA, Reimschisel TE, Schaaf CP, Potocki L, Scaglia F, Gambin T, Sykulski M, Bartnik M, Derwinska K, WisniowieckaKowalnik B, Lalani SR, Probst FJ, Bi W, Beaudet AL, et al:: Detection of clinically relevant exonic copy-number changes by array CGH. Hum Mutat 2010, 31:1326-1342.

28. Kirchheiner J, Schwab M: Heterogeneity of drug responses and individualization of therapy (Chapter 16). In Pharmacology and Therapeutics. Principles to Practice. Edited by Waldman SA, Terzic A. Philadelphia: Elsevier; 2008:225-238.

29. Pirmohamed M: Acceptance of biomarker-based tests for application in clinical practice: criteria and obstacles. Clin Pharmacol Ther 2010, 88:862-866.

30. Makawita S, Diamandis EP: The bottleneck in the cancer biomarker pipeline and protein quantificatioin through mass spectrometry-based approaches: current strategies for candidate verification. Clin Chem 2010, 56:212-220.

31. Umar A, Kang H, Timmermans AM, Look MP, Meijer-van Gelder ME, den Bakker MA, Jaitly N, Martens JW, Luider TM, Foekens JA, Pasa-Tolić L: 
Auffray et al. Genome Medicine 2011, 3:6

Page 5 of 5

http://genomemedicine.com/content/3/1/6

Identification of a putative protein profile associated with tamoxifen therapy resistance in breast cancer. Mol Cell Proteomics 2009, 8:1278-1294.

32. Blonder J, Veenstra TD: Clinical proteomic applications of formalin-fixed paraffin-embedded tissues. Clin Lab Med 2009, 29:101-113. doi:10.1186/gm220

Cite this article as: Auffray C, et al:: Genome Medicine: past, present and

future. Genome Medicine 2011, 3:6. 